\title{
Research on Visual Interpretation and Spatial Distribution Pattern of the Erosion Gully in Luoyugou Watershed of China
}

\author{
Wenyin Zhang ${ }^{1} \&$ Yinfeng Liu ${ }^{1}$ \\ ${ }^{1}$ School of Information Science and Engineering, Linyi University, Linyi, P. R. China \\ Correspondence: Yinfeng Liu, School of Information Science and Engineering, Linyi University, 276005, Linyi, \\ P. R. China. E-mail: lyfly1977@163.com
}

Received: April 28, 2019

Accepted: June 1, 2019

Online Published: June 26, 2019

doi:10.5539/enrr.v9n3p23

URL: https://doi.org/10.5539/enrr.v9n3p23

\begin{abstract}
There are criss-cross Ravines and gullies in the Loess Plateau, where the erosion gullies grows better. The loess material, which is loose and has the vertical jointing, is easy to suffer from the erosion; the types of erosion in this area mainly include gravitational erosion and the trench erosion. There are typical gulling erosion in Luoyugou watershed of Tianshui northern suburb, located in the interactive region of Longxi Loess plateau hill-gully area and the Longnan mountainous area. Under the support of the SPOT satellite photos in 2008 and field survey, the paper establishes the visual interpretation features of erosion gully, extracting the information of erosion gully, and uses the landscape pattern analytical method, studying the spatial distribution pattern of the erosion gully in the watershed. Finally, the paper draws the following conclusions: 1) The shapes of erosion gullies are strip or arborization, and in the black-white image, the stable erosion gullies appear deep dark color, active erosion gullies present the bright color, and half-active erosion gullies are the shallow dark color; while in color synthesis image, the color of stable erosion gullies mixes garnet, and other erosion gullies are bright green. 2) There are more erosion gullies in the study area where human activities occur frequently, such as the both sides of terraced field, the side of road and the river marshland, the both sides of terraced field have. 3) The erosion gullies in the study watershed are primarily stable ones, whose area accounts for $51.3 \%$ of the total erosion gullies, and half-active ones accounts for $18.3 \%$. This phenomenon indicates the progress in the control of the erosion gullies in this basin. 4) From the upstream to the downstream in the research basin, the erosion gully's average shape index has the tendency to reduce gradually, illustrating that the more getting nearly to the downstream, the more the slope of erosion gully to be gentler. The data results match well with the actual terrain feature.
\end{abstract}

Keywords: Erosion Gully, Visual Interpretation, Landscape Pattern, Luoyugou Watershed

\section{Introduction}

The impact of soil erosion is a serious global environmental problem (Williams et al., 1983; Renard, 1996; Castillo et al., 2016). Soil erosion can damage the land resource, causes the drop of soil productivity, the underproduction of crops, the sediment-depositing of rivers, streams, lake, reservoir and pond, the water pollution (Valentin et al., 2005; Poesen, 2011), moreover, the aggravation of drought and flooding disasters, and leads to a series of ecoenvironmental issues which poses a serious threat to human survival and socio-economic sustainable development, and has already received the general concern of the international community (Wu et al., 2002; Cohrane \& Flanagan, 1999). There are the most serious soil erosions in China, whose scope of soil erosion appears throughout the country (McCloskey et al., 2016). The causes of soil erosion are complex and the threat is serious (Omid et al., 2017; Hamid et al., 2017; Pourghasemi et al., 2017). The main erosion types include water erosion, wind erosion, gravity erosion, freeze-thaw erosion and glacial erosion. As one of the most serious erosion areas in Yellow River Basin as well as the whole country, the Loess Plateau's land resources and ecological environment have been greatly damaged. There are 7 types of loess gully, including rill, shallow gully, gully, hanging gully, gulch, and the brook (De Roo., 1996; Makanzu et al., 2014). The former 4 types are modern erosion gully and the latter two types are the ancient; some of gulches are modern, and some are ancient, whose Geological Time is roughly the Holocene Era.

Functional tree, naïve bayes tree (Mohsen et al., 2019), random forest model, specifically support vector machine, artificial neural network, certainty factor (Aykut \& Necdet, 2011; Federica et al., 2011) and maximum entropy 
models (Ali., 2019) are used for the mapping of the gully erosion susceptibility map, which can be used for road development, urbanization and other future development.

In order to reduce the harmful effects of soil and water loss, over the past 50 years, especially since the past 20 years, China has paid great importance to soil erosion in the Loess Plateau (Wu et al., 2002), and put a lot of manpower, material and financial resources, through governing typical small basins, returning farmland to forests and grasslands, vegetation construction, ecological restoration and other environmental policies and measures to reduce and control soil erosion. Although these measures have achieved some success, but to do a good job of prevention and mitigating of land degradation, we still need to make a great effort. Thus a comprehensive understanding of the distribution situation of erosion gully and its spatial distribution pattern has great significance to the study of the succession of landforms types in the region and soil erosion control (Simon et al., 2018).

\section{Summary of Study Area}

Luoyugou is located at East longitude $105^{\circ} 30^{\prime} \sim 105^{\circ} 45^{\prime}$, North latitude $34^{\circ} 34^{\prime} \sim 34^{\circ} 40^{\prime}$, belonging to the loess hilly and gully region of the middle reaches of the Yellow River, which is a tributary of the Wei River-a tributary ditch of Xihe River(Yu et al., 2006). The whole basin is under the government of Tianshui City (Figure 1), including five towns with 43 rural villages of Yuquan, Zhongliang in the District of Qinqun, Phoenix, Weinan, Henan in the North Road District and so on. This basin is the representative basin in the hilly-gully region of Loess Plateau. In 1983, Luoyugou watershed was ruled by the Yellow River Conservancy Commission as a test area of small basin, and the comprehensive management small basin focus by Gansu Province.

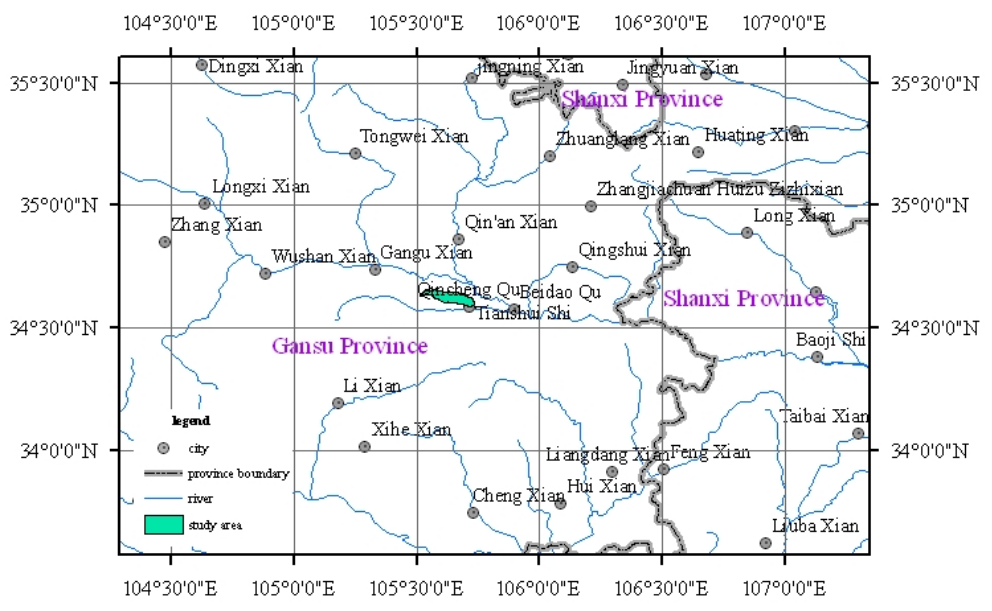

Figure 1. The situation map of Luoyugou watershed

The basin has a shape of plume and it shows a total area of $72.79 \mathrm{~km}^{2}$, with basin symmetric coefficient 0.9 , watershed development coefficient 1.49 . The length of the main gully of Luoyugou watershed is $21.81 \mathrm{~km}$. The left bank of the basin is high while the right is low. The relative relief between the upper reaches of the North Mouth is $275 \mathrm{~m}$, and $170 \mathrm{~m}$ of South Mouth. While the relative height difference between the lower reaches of the North Mouth is $270 \mathrm{~m}$, and $233 \mathrm{~m}$ of South Mouth. The highest point Phoenix Mouth is $1895.3 \mathrm{~m}$ above sea level, and the lowest point on the basis of ditch in Zuo Jiachang section is $1190 \mathrm{~m}$ above sea level, with maximum relative elevation $705.3 \mathrm{~m}$, the average basin elevation $1481.7 \mathrm{~m}$.

Luoyugou is continental monsoon climate, annual average temperature is $10.7^{\circ} \mathrm{C}$ (Yu et al., 2006). The highest temperature appears in July with the monthly average of $22.6^{\circ} \mathrm{C}$. While the lowest temperature in January with the monthly average of negative $2.8^{\circ} \mathrm{C}$. Due to the impact of monsoon's changes with seasons, the distribution of precipitation is very uneven, drought in winter and spring, the precipitation concentrating in summer and autumn. Though the same quarter in hydrothermal features is conducive to the growth of crops, yet because of the big change of inter-annual precipitation every month, it is prone to appear drought or flood and the local high-intensity heavy rain or rainstorm is easy to happen in summer or autumn, leading to serious soil erosion, and bringing disaster for agricultural production.

There are totally 49 families and 230 kinds of major higher plants in Luoyugou basin, including 39 kinds of arbors, 19 kinds of shrubs and 172 kinds of herbs. The whole basin is divided into five cluster groups, 20 floras, and 26 sub-floras. 


\section{Data Sources and Research Methods}

\subsection{Data Sources}

Data that the paper introduced includes three parts.

One is from remote sensing image data of SPOT of May of 2008. Image was acquired from the SPOT image company. Then the SPOT image is used to do ortho-rectification by 1:1 million DEM data and 1:5 million topographic map data. Finally we get digital ortho-image that has been corrected.

The other part is from the field survey data in May of 2009. Through the field survey to the Luoyugou Watershed of Tianshui, Gansu Province, access to latitude, longitude and elevation data of typical erosion gully survey point, and hand-painted records of the general shape of the erosion gully. Then we import GPS data to ARCGIS Software, generate point layers, then generate line layers, superposition with ortho-image and comparative and analysis, determine the interpret signs of erosion gully.

Another is the topographic map of Tianshui, Gansu Province in 1980s. The topographic map is 1:5 million scale topographic map, including paper topographic map and digital line graphic data.

\subsection{Research Methods}

\subsubsection{Method of Visual Interpretation}

Conventional visual interpretation methods of remote sensing images are as follows.

1) Direct interpretation. The method determines the properties and scope of the target object directly by visual interpretation of the direct signs of remote sensing images.

2) Comparative analysis. The Comparative analysis method includes three methods of comparative analysis of similar features, spatial comparative analysis and dynamic contrast with real time images.

3) Composite information. A method, by using transparent thematic map or transparent topographic map overlap with remote sensing image, to recognize the target object on the remote sensing image according to the variety of supplementary information provided by thematic maps or topographic map.

4) Integrated reasoning method. A method that considered the variety of the interpret characteristics of remote sensing image integrated, and combined with knowledge of life, to analysis and inference of a target object.

5) Geographical correlation analysis. Based on the interdependence, mutual checks and balance relationship that among various geographical elements in Geographical environment, with expertise, to analysis and determine the nature, type, status and distribution of a geographical elements.

\subsubsection{GIS Hydrological Analysis}

The main content of analysis of surface hydrological basing on DEM is to extract water flow direction, convergence cumulant, flow length, river networks (including the classification of river networks) and the demarcation of basin in study area by hydrological analysis tools (Ye, 2005). The paper uses the tool of basin demarcation.

The basin demarcation method includes three parts: determination of drainage basins, determination the outlet of catchment area and the formation of catchment. The drainage basin is catchment area divided by watershed. The grids connected with one another in the same drainage basin are determined by the analysis of the water flow direction. The first step to determine the drainage basin is to find out the outlet position at the edge of the analysis window, then to figure out the position of the all grids of the upper reaches of outlet. The method of the determination of catchment area is somewhat like contribution area in low-lying land. In ARCGIS, the drainage basin hydrology calculation tool is based on the use of basin tool of hydrology tools. The drainage basin determined from last step is a relatively bigger one. Many hydrological analysis need to be done on smaller basin unit .outlets of smaller level of basin can be determined by snap pour point tool from spatial analysis tools, which is the determination of outlet of catchment. The catchment of smaller level can be generated by the watershed tool from hydrology tools. The idea is as following, first, to determine a outlet point, saying the lowest point of the catchment, then to search and analysis every grid that goes through the point according to the flow direction. The determination of the grid of the catchment area leads to the determination of boundary of the area, forming the catchment area.

\subsubsection{Landscape Pattern Analysis}

On the analysis of the distribution of erosion gully, this paper draws on the experience of the landscape pattern method, selecting the four indicators of the perimeter, area, density and shapes index to analyze the distribution of erosion gully. 
1) Perimeter of erosion gully. 2) Area of erosion gully. 3) Density of erosion gully (Formula 1): The number of erosion gully per square kilometer (GD) and the area (GS). (4)Shape index (Formula 2) (Wu, 2000): Erosion gully's shape index refers to that the area of erosion gully divided by its perimeter, then got the square root, and multiplied the square calibration constant. Range: GSL $\geqq 1$, no upper limit. It shows the shape of gully erosion in the degree of deviation from the square. The greater the value is, the bigger the degree that deviation from the square, and it would be much easier to be in long and narrow shape. It reflected the extent of steep relief of the gradient. Then according to that, we could analysis the shape features of the erosion gully.

$$
G D=N / S_{\text {total }}, G S=S / S_{\text {total }}
$$

$N$ is the total number of erosion gully. $S$ is the total area of erosion gully. $S_{\text {total }}$ is the area of watershed.

$$
G S L=0.25 E / S
$$

GSL is the shape index of erosion gully. $\mathrm{E}$ is the perimeter of erosion gully. $\mathrm{S}$ is the area of erosion gully.

\subsection{The Flow Chart of the Research}

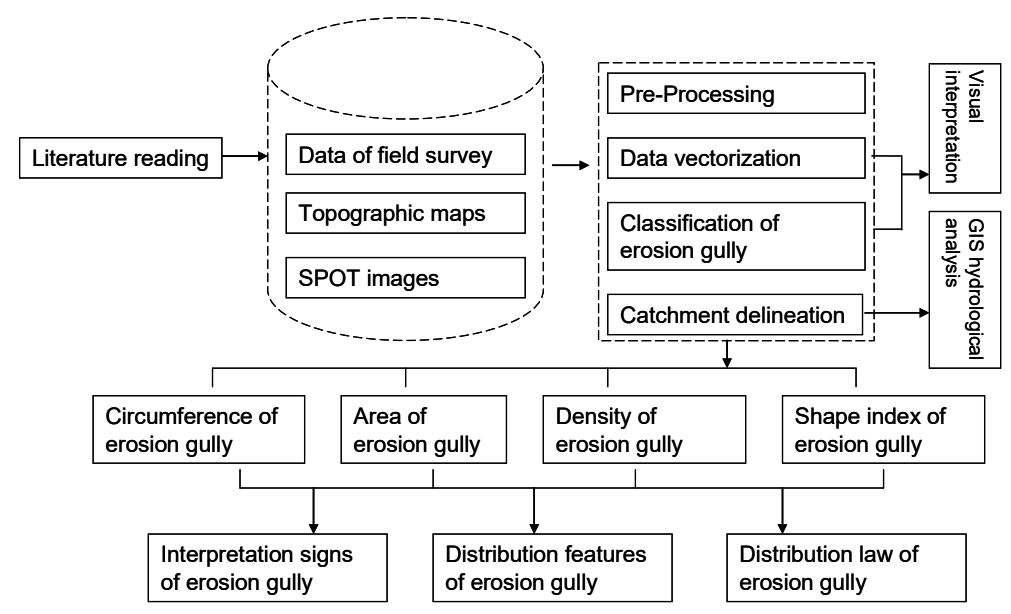

Figure 2. The flow chart of the research

\section{Result Analysis}

\subsection{Visual Interpretation}

According to field surveys and researches home and abroad, the erosion gully can be classified into three types: active type erosion gully, semi-active type erosion gully and stable type erosion gully (Wu et al., 2002; Yan et al., 2005). The classification principles are shown as the stable below.

According to Figure 3, visual interpretation is done on Luoyugou Basin and we draw 214 erosion gullies. The interpretation result of erosion gully in Luoygou Basin is as follows.

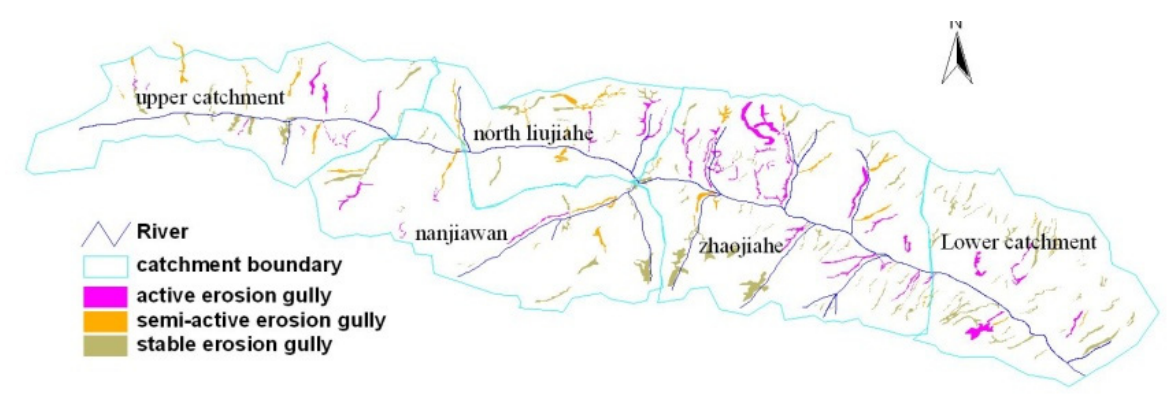

Figure 3. The distribution of erosion gully in Luoyugou watershed 
Table 1. Classification of gully erosion and index of image interpretation

\begin{tabular}{|c|c|c|c|}
\hline $\begin{array}{l}\text { Type of erosion } \\
\text { gully }\end{array}$ & Classification Principle & $\begin{array}{l}\text { Image } \\
\text { Feature }\end{array}$ & Index of Image Interpretation \\
\hline Active type & $\begin{array}{l}\text { There is no stable deposits at the gully bottom } \\
\text { and is often covered with bare soil because of the } \\
\text { constant incise of the grooves. }\end{array}$ & $\begin{array}{l}\text { Bright white } \\
\text { on SPOT } \\
\text { image. }\end{array}$ & $\begin{array}{l}\text { 1) Erosion position is near the aggregation of } \\
\text { local human activities, such as terrace, road and } \\
\text { dry river. }\end{array}$ \\
\hline Semi-active type & $\begin{array}{l}\text { The incise of grooves slows down. There are } \\
\text { some deposits at the gully bottom and year plant } \\
\text { but vegetation is sparse. }\end{array}$ & $\begin{array}{l}\text { Light dark on } \\
\text { SPOT image }\end{array}$ & $\begin{array}{l}\text { 2) geomorphology: There are many deep gullys, } \\
\text { slope are steep and the landscape is fractured. } \\
\text { 3) shape: rectangular or dendritic. }\end{array}$ \\
\hline Stable type & $\begin{array}{l}\text { The groove incise almost stops. The profile at } \\
\text { gully bottom is near the balance profile. There } \\
\text { are many deposits and plants at gully bottom and } \\
\text { gully wall like bush, dungarunga and planted } \\
\text { forest. }\end{array}$ & $\begin{array}{l}\text { Deep dark on } \\
\text { SPOT image }\end{array}$ & $\begin{array}{l}\text { 4) color: On the images in the panchromatic } \\
\text { band, erosion gully with good vegetation is dark. } \\
\text { The vegetation with broad-leaved forest } \\
\text { (Robinia pseudoacacia) and grassland is dark } \\
\text { red; the erosion gully with less vegetation is } \\
\text { bright. } \\
\text { 5) shadow: little shadow and light color. } \\
\text { 6) Texture structure: The Erosion channel is } \\
\text { obvious and of long strips. }\end{array}$ \\
\hline
\end{tabular}

\subsection{Demarcation of Sub-Basin}

Basin, also known as catchment basin, is concentration of the drainage area which is formed by water and other substances that discharge from a common outlet. A natural drainage network is usually a composition of channels with various sizes and shapes. Every channel has its unique features, such as the catchment area, also known as the drainage area. A bigger basin is often composed of smaller ones.

In this paper, flow information is used to extract the drainage networks and then to determine the boundary lines of sub-catchment from DEM data. To investigate the discontinuity of the drainage network, we performed the drainage network delineation by water flow. There are three steps for the Terrain Analysis using Digital Elevation Models. 1) One step is to calculate the flow direction (the water flow direction when it leaves the grid) of every unit; 2) Two step is to determine the cumulative flow matrix by the direction; 3) Three step is to choose a threshold and connect the points where the cumulative water flow value is higher than the threshold, which forms a drainage network.

Based on the trend and height distribution of Luoyugou and according to the GIS hydrological analysis, the Luoyugou Basin can be divided into five sub-catchments, which respectively are upper reaches of Luoyugou Basin, northern part of Liujiahe Basin, Nanjiawan Basin, Zhaojiahe Basin and lower reaches of Luoyugou Basin, as shown in Fig.3. Northern part of Liujiahe Basin, Nanjiawan Basin, Zhaojiahe Basin are located in the middle reaches of Luoyugou Basin. Northern part of Liujiahe Basin and Nanjiawan Basin are located in northern slope of the southern slope of Luoyugou and differ considerably in topographical features, which are therefore divided into two sub-basins. Zhaojiahe Basin is located in the middle and lower reaches of Luoyugou, whose elevation is relatively low and therefore is separated as a sub-catchment. The classification results are shown in Fig.3.

\subsection{The Distribution of Erosion Gully}

\subsubsection{Various Types of Distribution Analysis of Erosion Gully}

Through a function of ARCGIS software, the area of the erosion gully, perimeter and shape index (formula 1), are calculated, in which the total number of erosion gully is 224 , a total area is $3.69 \mathrm{~km}^{2}$, the total circumference of $282.40 \mathrm{~km}$, by the formula (2) derived density: $\mathrm{GD}=3, \mathrm{GS}=0.051$. Different types of erosion gully such as area indicators in Table 2.

(1) Perimeter/ area ratio of various types of erosion Gully. From Table 2, we can see the largest number of stable erosion gully for the 144 , the perimeter for the $141.36 \mathrm{~km}$, and the area of $1.90 \mathrm{~km}^{2}$. We can see from the perimeter /area ratio the stable erosion gully is mainly, accounted for $51.3 \%$ of the total area, non-active erosion gully accounted for $18.3 \%$, indicating that the basin Management has been progress for erosion gully. However, $30.4 \%$ of active erosion gully still shows that the destructive area of soil erosion is still relatively large. 
Table 2. Distribution of erosion gully Overview

\begin{tabular}{|c|c|c|c|c|}
\hline \multicolumn{2}{|c|}{ the type of erosion gully } & active Erosion gully & Non-active Erosion gully & stable Erosion gully \\
\hline \multicolumn{2}{|c|}{ Number / } & 44 & 36 & 144 \\
\hline \multicolumn{2}{|c|}{ aera $/ \mathrm{km}^{2}$} & 1.12 & 0.68 & 1.89 \\
\hline \multicolumn{2}{|c|}{ circumference $/ \mathrm{km}$} & 87.23 & 53.81 & 141.36 \\
\hline \multicolumn{2}{|c|}{ Perimeter / area ratio } & 77.80 & 79.71 & 74.72 \\
\hline \multicolumn{2}{|c|}{ Shape index } & 10.816 & 9.431 & 7.64 \\
\hline \multirow{2}{*}{ Density } & GD & 0.591 & 0.467 & 1.882 \\
\hline & GS & 0.015 & 0.009 & 0.026 \\
\hline \multirow{3}{*}{ Shape index } & $\mathrm{GSL}_{\max }$ & 19.594 & 18.487 & 15.197 \\
\hline & $\mathrm{GSL}_{\text {mean }}$ & 10.816 & 9.432 & 7.640 \\
\hline & $\mathrm{GSL}_{\min }$ & 5.766 & 2.318 & 3.202 \\
\hline
\end{tabular}
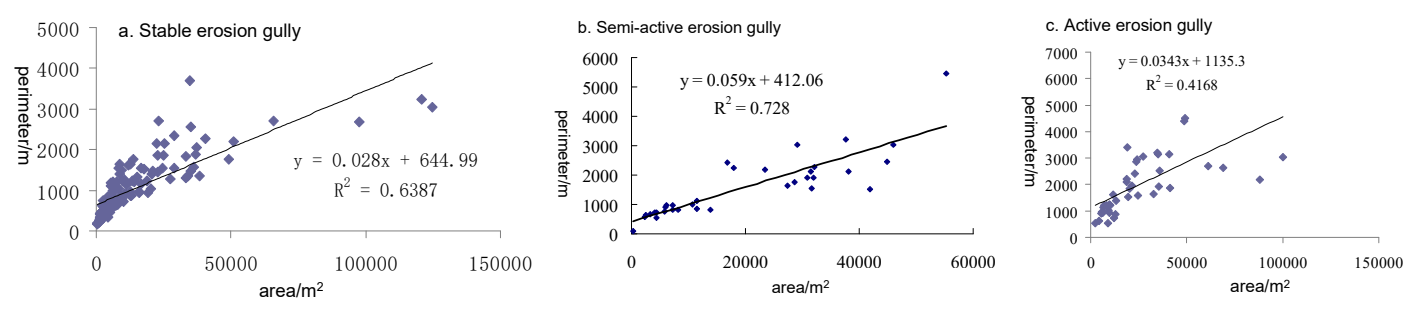

Figure 4. The area-perimeter scatter map of three types of erosion gully

Changes of the circumference /area ratio of the stable erosion gully changes is smallest (Figure 4), that is the type of erosion gully with the increase in circumference of at least an area of growth.
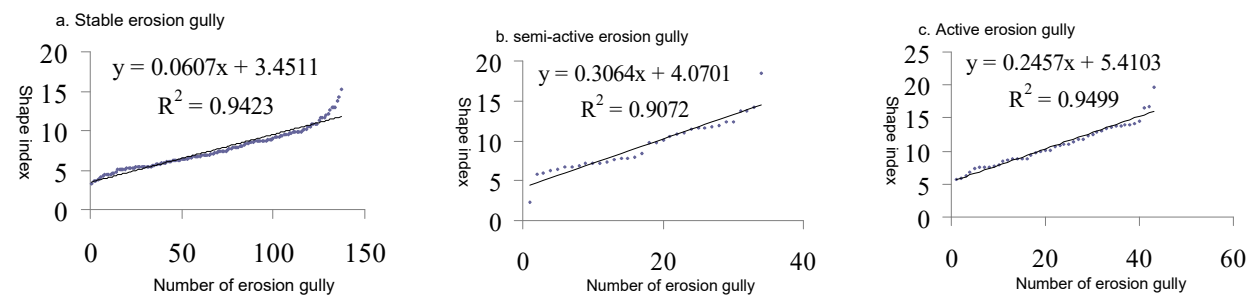

Figure 5. The shape index of three types of erosion gully

Through the scatter plot (Figure 5) to draw the trend line, three types of erosion gully linear relevance were 0.949 , $0.907,0.942$, the relevance were larger, this can be used to express the erosion gully, and the changes in the shape of index of stable erosion was 0.060 , compared with other two types was smaller, showed that the shape of the stability characteristics of erosion gully is more evenly, are relatively gentle slope, the other two types are relatively long and narrow.

The average GSL of active erosion gully is 10.816 , non-active erosion gully is 9.432 , and the stable erosion gully is 7.640, it can be seen, the shape index of active erosion gully, non-active erosion gully, stable erosion gully present the trend of decreasing level, indicating active erosion is the most long and narrow, the slope is steepest, followed by non-active erosion gully, the end is stable, so that it can draw the causes of erosion gully, because narrow and steep slope erosion, channel erosion caused by rainfall more serious, lack of stability deposits, vegetation can not grow, this is non-active erosion gully, slope erosion alleviate some of the trenches. At the bottom of the valley are a small number of the deposits, a small amount of plant growth, it developed into a non-active erosion gully. And slope of erosion gully is smaller, more sediment, the growth of a large number of plants, thus are the stable erosion gully.

\subsubsection{Distribution Analysis of the Sub-Watershed}

Extract the shape index of erosion gully in various sub- watershed, and statistic the largest, and the youngest, with an average value, see Table 3 . 
Table 3. The shape index Sub-watershed of Erosion gully

\begin{tabular}{|c|c|c|c|c|c|}
\hline $\begin{array}{l}\text { sub- watershed } \\
\text { name }\end{array}$ & $\begin{array}{l}\text { upstream in } \\
\text { Luoyugou }\end{array}$ & $\begin{array}{l}\text { Liujiahe } \\
\text { watershed }\end{array}$ & $\begin{array}{l}\text { Nanjiawan } \\
\text { watershed }\end{array}$ & $\begin{array}{l}\text { Zhaojiahe } \\
\text { watershed }\end{array}$ & $\begin{array}{l}\text { downstream in } \\
\text { Luoyugou }\end{array}$ \\
\hline The largest $G S L$ & 19.594 & 18.487 & 14.153 & 16.763 & 15.197 \\
\hline The samllest $G S L$ & 5.766 & 3.202 & 3.775 & 2.318 & 3.981 \\
\hline The average $G S L$ & 10.816 & 9.388 & 8.973 & 8.579 & 8.211 \\
\hline
\end{tabular}

Table 3 shows that the average shape index of erosion gully presents a gradual decrease from the upstream to downstream, this show that the more gentle slope in downstream, the data of the study results with the actual topographical features are in line, while three sub-basin from the middle, the shape index of the erosion gully can be seen, the northern slope, located in Liujiahe watershed is greater than the southern slope of Nanjiawan watershed, which show that the northern slope is relatively narrow.

\subsection{Location Analysis of Erosion Gully}

\subsubsection{Analysis on Remote Sensing Image}

From erosion gully remote sensing interpretation signs (Table 1), we can see that erosion gully are mainly distributed in the more frequent human activities, such as on both sides of the terraced fields, the sides of the roads and rivers, according to the field survey, the location of the vulnerability of gravity, and water erosion. Different types of erosion gully, with the soil erosion situation and the different evolutionary history. Active erosion gully is generally steep river flow, because of uncertainty rainfall, when there are heavy rains, the surface runoff along the river washed away the debris so that the growth of vegetation can not be a long time. Stable erosion gully are located in the terraced fields, the sides of the roads, on the one hand because of its flat slope on the other hand, through artificial control of soil erosion by planting vegetation, erosion gully has become stable. The spatial distribution of non-active erosion gullies shows no regular arrangement.

\subsubsection{Indicators Analysis}

We extract the number of three type erosion gully of the sub-watershed, and we get Table 4 .

Table 4. Classification of the number of Erosion gully in sub-watershed

\begin{tabular}{|c|c|c|c|c|c|c|}
\hline \multirow{2}{*}{ watershed name } & \multirow{2}{*}{ upstream } & \multicolumn{3}{|c|}{ Middle stream } & \multirow{2}{*}{ Down stream } & \multirow{2}{*}{ total } \\
\hline & & Liujiahe & Nanjiawan & Zhaojiahe & & \\
\hline Active Erosion gully & 8 & 3 & 4 & 22 & 7 & 44 \\
\hline Non-active Erosion gully & 6 & 5 & 6 & 13 & 6 & 36 \\
\hline Stable Erosion gully & 12 & 14 & 18 & 54 & 46 & 144 \\
\hline
\end{tabular}

Table 4 shows that the proportion of active erosion gully in the upper stream is greater than middle and downstream, the downstream, the proportion of the stable erosion gully greater, for mid-stream, the number of erosion gully in the upper stream less than of the middle stream and downstream, the number of the northern slope less than of the southern slope of gully erosion. This is due to the downstream, the more gentle terrain, the easier the formation of stable erosion gully, and the terraced fields in the southern slope are more severe impact on human activities, the easier the formation of erosion gully.

\section{Conclusions}

Based on the SPOT remote sensing image manual interpretation, multi-indexes of erosion gully were obtained, spatial distribution of erosion gully features were analyzed, the quantity of channel erosion was simulated by geometric simulation, and the conclusions were following:

(1) Erosion gully SPOT remote sensing image center interpretive signs

Topography of erosion gully is characterized by more gullies, steeper slope, deeper ditch, and terrain fragmented landform. The shapes of erosion gully are all long strip or dendrites. On the Monochrome, vegetation cover of stable erosion gully is better, with a deep dark, and the broad-leaved forest (Robinia pseudoacacia) and grassland mainly covered in these areas. The vegetation coverage of active erosion gully is so little that active erosion gully shows a bright color. Semi-active erosion gully is shallow dark. Stable erosion gully in color composite image is a mixture of dark red color, and other erosion gully is bright green.

(2) Distribution of distribution and geographical elements in the watershed erosion gully 
More human activity areas such as terraces both sides, the sides of the roads and the dried up river. Human farming activities would be due to accelerating soil erosion on the both sides of the terraces. Construction roads cause would mountain bareness along the roads. Vegetation protection losing in the hill, loose soil on the road, and mountain bareness weakened anti-soil erosion ability. While the seasonal drying up of river channel, the new channel precipitation will cause further erosion. So erosion gully in these places is a more local distribution.

(3) Characteristics of various types of erosion gully

Erosion gully are mainly stable erosion gully in studied watershed, which is accounted for 51.3 percent of the total area, semi-active erosion gully accounted for $18.3 \%$.that is to say, it has been some progress in watershed management, but there is still $30.4 \%$ for the active erosion gully, means that soil erosion in the region against the still relatively large. Shape index of three types of erosion gully is the trend of decreasing level. Active erosion is the most long and narrow groove, and the steepest slope, while slope of the stable erosion gully is the most relief.

(4) Characteristics of the sub-watershed erosion gully

From the Upstream to downstream in the watershed, the average shape index has a gradually decreased trend. That is to say, the more downstream, the gentler slope of the ditch is which coincide with the actual topographical features of the watershed. It is can be seen from the shape index of the three sub-basin erosion gully in middle reaches, the shape index of the northern area of Liujiahe basin in Luoyugou middle reaches, is more than southern slope of the Nanjiawan basin. This means the northern slope of the erosion gully is relatively long and narrow shape. The ratio of area and perimeter located in the northern area of Liujiahe basin of middle reaches is significantly greater than other sub-basins on the middle reaches. This means erosion intensity of the northern area of Liujiahe basin of middle reaches is the largest.

In view of the reasons for the time and information, the study of this article has some areas for improvement. Mainly in following:

1) Although the survey erosion gully is more representative, only a relatively small number which is less than needed, and Field authentication of various types erosion gully are needed.

2) The SPOT image in 2008 combined with the measured data were analyzed, if the work more perfect, It is best to analyze several periods, to study the Dynamic changes of the watershed erosion gully, and reflect the effect of the control, in order to put forward an effective ways to further treatment the erosion gully.

\section{Acknowledgements}

This research was carried out with financial support from the Shandong provincial Key Research and Development Program of China (2017CXGC0701). The authors are grateful to the journal's editor and anonymous reviewers for their constructive comments on earlier version of this paper.

\section{Conflict of interests}

The authors declare that there is no conflict of interests regarding the publication of this paper.

\section{References}

Akgün, A., \& Türk, N. (2011). Mapping erosion susceptibility by a multivariate statistical method: a case study from the Ayvalik region, NW Turkey. Computers \& Geosciences, 37, 1515-1524.

Azareh et al. (2019). Modelling gully-erosion susceptibility in a semi-arid region, Iran: Investigation of applicability of certainty factor and maximum entropy models. Science of the Total Environment, 655, 684696.

Castillo, C., \& Gómez, J. A. (2016). A century of gully erosion research: Urgency, complexity and study approaches. Earth-Science Reviews, 160, 300-319.

Cohrane, T. A., \& Flanagan, D. C. (1999). Assessing water erosion in small watersheds using WEPP with GIS and digital elevation models. Journal of Soil and Water conservation, 678-685.

De Roo, A. P. J., Wesseling, C. G., \& Ritsema, C. J. (1996). LISEM: A single-event physically based hydrological and soil erosion model for drainage basins; I: theory, input and output. Hydrological Processes, 10(8), $1107-$ 1117.

Hosseinalizadeh et al. (2019). Gully headcut suscepbility modeling using functional tree, naïve bayes tree and random forest models. Geoderma, 342, 1-11.

Luca, F., Conforti, M., \& Robustelli, G. (2011). Comparison of GIS-based gullying susceptibility mapping using bivariate and multivariate statistics: Northern Clabria, South Italy. Geomorphology, 134, 297-308. 
Makanzu Imwangana, F., Dewitte, O., Ntombi, M., \& Moeyersons, J. (2014). Topographic and road control of mega-gullies in Kinshasa (DR Congo). Geomorphology, 217, 131-139.

McCloskey, G. L., Wasson, R. J., Boggs, G. S., \& Douglas M. (2016). Timing and causes of gully erosion in the riparian zone of the semi-arid tropical Victoria River, Australia: Management implications. Geomorphology, 266, 96-104.

Poesen, J. (2011). Challenges in gully erosion research. Landform Analysis, 17, 5-9.

Porughasemi et al. (2017). Performance assessment of individual and ensemble data-mining techniques for gully erosion modeling. Science of the Total Environment, 609, 764-775.

Pourghasemi et al. ( 2017). Performance assessment of individual and ensemble data-mining techniques for gully erosion modeling. Science of The Total Environment, 609, 764-775.

Pulley et al.(2018). Gully erosion as a mechanism for wetland formation: An examination of two contrasting landscapes. Land Degradation \& Devlopment, 29, 1756-1767.

Rahmati et al. (2017). Evaluation of different machine learning models for predicting and mapping the susceptibility of gully erosion. Geomorphology, 298, 118-137.

Renard, K. G. (1996). Predicting soil erosion by water: A guide to conservation planning with the revised universal soil loss equation (RUSLE). Agriculture Handbook, 537.

Valentin, C., Poesen, J., \& Yong, L. (2005). Gully erosion: impacts, factors and control. Catena, 63(2), $132-153$.

Williams, J. R., Renard, K. G., \& Dyke, P. T. (1983). EPIC: A new method for assessing erosion's effect on soil productivity. Journal of Soil and Water Conservation, 38(5), 381-383.

Wu, J. G.(2000). Landscape Ecology Pattern Process, Scale and Hierarchy (pp. 100-119). Beijing: High Education Press.

Wu, Y. N., Zhang, H. L., \& Yang, L. P. (2002). A preliminary analysis on soil erosion of Yellow River Basin in Gansu. Remote Sensing Technology and Application, 17(6), 398-401.

Yan et al. (2005). Temporal and spatial variation of erosion gullies in Kebai black soil region of Heilongjiang during the past 50 years. ACTA Geograhica Sinca, 60(6), 1015-1020.

Ye et al. (2005). Drainage network extraction and subcatchment delineation based on digital elevation model. Journal of Hydraulic Engineering, 5, 531-537.

$\mathrm{Yu}$ et al. (2006). Effects of vegetation cover and precipitation on the process of sediment produced by erosion in a small watershed of loess region. Acta Ecologica Sinica, 26(1), 1-8.

\section{Copyrights}

Copyright for this article is retained by the author(s), with first publication rights granted to the journal.

This is an open-access article distributed under the terms and conditions of the Creative Commons Attribution license (http://creativecommons.org/licenses/by/4.0/). 